\title{
Pensando o espaço de todos: Milton Santos e a construção do campo do planejamento urbano e regional
}

\section{Thinking everyone's space: Milton Santos and the construction of the field of urban and regional planning}

Gabriel Leite - Geógrafo, Mestre em Planejamento do Desenvolvimento pelo Núcleo de Altos Estudos Amazônicos da Universidade Federal do Pará (NAEA/UFPA). Pesquisador do Grupo de Estudos e Pesquisas sobre Ordenamento Territorial e Urbanodiversidade na Amazônia (GEOURBAM). E-mail: gabrielcarvalholeite16@gmail.com

\section{Resumo}

$\mathrm{O}$ artigo busca investigar a presença do planejamento urbano e regional como um objeto de reflexão interpretativa e propositiva na obra do intelectual brasileiro Milton Santos. Com base em extensa pesquisa bibliográfica e documental, complementada por entrevistas semiestruturadas com alguns de seus interlocutores, são discutidas as interseções entre as trajetórias do geógrafo em referência e a do planejamento urbano e regional, bem como o legado miltoniano para esse campo do conhecimento. $\mathrm{O}$ artigo conclui que o papel de Milton Santos na construção do campo do planejamento urbano e regional foi o de um intelectual crítico comprometido com o futuro do espaço de todos.

\section{Palavra-chave}

Milton Santos. Planejamento Urbano e Regional. Legado Intelectual. Espaço de Todos.

\begin{abstract}
The article seeks to investigate the presence of urban and regional planning as an object of interpretive and propositive reflection in the work of the Brazilian intellectual Milton Santos. Based on an extensive bibliographic and documentary research, complemented by semistructured interviews with some of his interlocutors, the intersections between the geographer's trajectory and that of the urban and regional planning are discussed, as well as the Miltonian legacy for this field of knowledge. The article concludes that Milton Santos' role in the construction of the field of urban and regional planning was that of a critical intellectual committed to the future of everyone's space.
\end{abstract}

\section{Keywords}

Milton Santos. Urban and Regional Planning. Intellectual Legacy. Everyone's Space. 


\section{INTRODUÇÃO}

Poucos campos do conhecimento expressam tão bem a indissociabilidade entre o descritivo e o normativo, o interpretativo e o operativo, quanto o planejamento urbano e regional. Diríamos, inspirados em Japiassu (1975), que este é um campo praxeológico, pois nele o desenvolvimento e a elaboração das ideias e das teorias científicas são sempre acompanhados da vontade de intervir e transformar a realidade social. Por isso, quando se busca resgatar o legado intelectual de pensadores de referência para o planejamento, não há como perder de vista essa dimensão praxeológica que lhe é inerente.

Neste artigo $^{1}$, é de um desses pensadores, o geógrafo brasileiro Milton Santos, e de sua praxeologia que se pretende tratar. Em particular, interessanos investigar a presença do planejamento urbano e regional como objeto de reflexão interpretativa e propositiva na obra miltoniana, amplamente reconhecida pelas suas contribuições às teorias críticas do espaço, do subdesenvolvimento, da urbanização e da globalização, mas não comumente associada ao tema do planejamento. Afinal, constituiu este uma preocupação na trajetória intelectual do geógrafo em referência? Se sim, foi uma problemática acessória ou, pelo contrário, assumiu centralidade no desenvolvimento de suas principais formulações teóricas?

Para responder a essas perguntas, adota-se como procedimento metodológico o levantamento da produção bibliográfica ${ }^{2}$ e dos documentos pessoais $^{3}$ do autor que mais diretamente indicam o seu engajamento no campo do planejamento urbano e regional. Complementarmente, a fim de esclarecer aspectos não totalmente elucidados no levantamento bibliográfico e documental, também foram realizadas entrevistas semiestruturadas com alguns de seus interlocutores.

Além da presente introdução, o artigo está estruturado em mais duas seções, seguidas das considerações finais. Enquanto a primeira seção apresenta uma visão panorâmica das interseções entre a trajetória intelectual e profissional de Milton Santos e a trajetória histórica do planejamento urbano e regional, a

\footnotetext{
As reflexões expostas no artigo sintetizam algumas das discussões desenvolvidas pelo autor na dissertação de mestrado intitulada "Por um ordenamento cívico do território: uma reflexão crítica sobre o planejamento urbano e regional a partir da obra de Milton Santos", defendida e aprovada no Núcleo de Altos Estudos Amazônicos da Universidade Federal do Pará (NAEA/ UFPA), em dezembro de 2019.

2 A produção bibliográfica selecionada inclui, principalmente, livros e capítulos de livros, artigos publicados em periódicos científicos e em jornais de ampla circulação e entrevistas concedidas pelo autor.

3 Trata-se dos documentos presentes no Fundo Milton Santos, integrante do acervo documental do Instituto de Estudos Brasileiros da Universidade de São Paulo (IEB/USP).
} 
segunda seção trata das principais contribuições que a obra miltoniana oferece ao referido campo do conhecimento. Por fim, à guisa de conclusão, são retomadas as questões norteadoras apresentadas nesta introdução a fim de pensar o lugar de Milton Santos no conjunto dos intelectuais brasileiros que participaram da construção do campo do planejamento urbano e regional.

\section{MILTON SANTOS E O PLANEJAMENTO URBANO E REGIONAL: TRAJETÓRIAS CRUZADAS DE UM INTELECTUAL E DE UM CAMPO DO CONHECIMENTO}

Nesta seção, acompanharemos duas trajetórias estreitamente relacionadas às grandes transformações do sistema político-econômico e territorial brasileiro no século XX. Não apenas foram elas contemporâneas entre si, mas também cruzadas. Em diferentes momentos, interseccionaram-se e contribuíram uma para a outra. Uma delas é uma trajetória individual, ainda que não individualista. A outra, uma trajetória coletiva que, no entanto, não prescindiu da ação de indivíduos notáveis. Estamos a nos referir, respectivamente, a um intelectual, o geógrafo Milton Santos, e a um campo do conhecimento, o planejamento urbano e regional.

Com preocupação esquemática, propomos aqui uma periodização que distingue três momentos no contexto dos quais as interseções entre as trajetórias mencionadas tornam-se mais inteligíveis. Se os enfocarmos do ponto de vista das atividades técnico-científicas e político-administrativas (Quadro 1), o primeiro período (de 1956 a 1964) aparece como aquele em que Milton Santos integrou a tecnoestrutura ${ }^{4}$ de planejamento do estado da Bahia, a primeira do gênero no Brasil; o segundo período (de 1965 a 1977) figura como o da inserção do geógrafo, então exilado, no circuito internacional de instituições, disciplinas e experts em planejamento do desenvolvimento no Terceiro Mundo ${ }^{5}$; e o terceiro período (de 1978 a 2001) caracteriza-se pela sua reinserção no Brasil por meio de atividades de consultoria e de ensino na área do planejamento urbano e regional, bem como pela sua atuação em importantes debates públicos e instituições acadêmicas desse campo do conhecimento no país.

\footnotetext{
O conceito de tecnoestrutura foi proposto por Ianni (1986) para se referir ao conjunto dos técnicos, instituições e meios necessários para a elaboração, execução e controle dos planos.

5 Durante o exílio, Milton Santos manteve uma rede de cooperação que incluiu tanto o aparato internacional de assistência técnica aos países subdesenvolvidos, a exemplo da Organização das Nações Unidas (ONU) e da Organização dos Estados Americanos (OEA), quanto as instituições nacionais que também participaram desse campo internacional de ideias e práticas de planejamento no Terceiro Mundo.
} 
Quadro 1 - Milton Santos e o planejamento urbano e regional: atividades técnicocientíficas e político-administrativas

\begin{tabular}{|c|c|}
\hline Perí & Atividades técnico-científicas e político-administrativas \\
\hline $\begin{array}{c}\text { 1956-1964: } \\
\text { Milton Santos e } \\
\text { o planejamento } \\
\text { urbano e regional } \\
\text { na Bahia }\end{array}$ & $\begin{array}{l}\text { - Direção do Laboratório de Geomorfologia e Estudos Regionais da } \\
\text { Universidade da Bahia (1959-64): } \\
\text { - formação de quadros técnicos e realização de pesquisas urbano-regionais } \\
\text { e ambientais no território baiano, sob demanda da administração estadual. } \\
\text { - Presidência da Fundação Comissão de Planejamento Econômico do } \\
\text { Estado da Bahia (1963-64): } \\
\text { - realização de pesquisas e elaboração de políticas de planejamento } \\
\text { econômico, urbano e regional. }\end{array}$ \\
\hline $\begin{array}{r}1965 \\
\text { Milton } \\
\text { o plane } \\
\text { urbano } \\
\text { no Terce }\end{array}$ & $\begin{array}{l}\text { - Exercício de atividades de ensino e pesquisa sobre ordenamento do } \\
\text { território e planejamento urbano e regional em instituições de vários } \\
\text { países: } \\
\text { Institut d'Études du Développement Économique et Social - IEDES, na França } \\
\text { (1967-71). } \\
\text { - Special Program for Urban and Regional Studies do Massacbusetts Institute of } \\
\text { Technology - SPURS/MIT, nos Estados Unidos (1971-72). } \\
\text { - Facultad de Ciencias Económicas y Sociales e Centro de Estudios del Desarrollo - } \\
\text { CENDES, na Universidad Central de Venezuela (1974). } \\
\text { - Facultad de Arquitectura y Urbanismo da Universidad del Zulia, na Venezuela } \\
\text { (1976). } \\
\text { - Columbia University, nos Estados Unidos (1976-77). } \\
\text { - Realização de cursos, pesquisas e missões técnicas por intermédio de } \\
\text { organismos internacionais: } \\
\text { - direção do Programa Venezuela Hoje, financiado pela ONU e por duas } \\
\text { instituições venezuelanas, a Oficina Central de Coordinación y Planificación e a } \\
\text { Comisión Nor-Oriental, para o estudo e o planejamento da urbanização no } \\
\text { país (1968-69). } \\
\text { - cursos na Universidad Nacional de Ingeniería, no Peru (1973), e na Costa } \\
\text { Rica (1975), por meio da OEA. } \\
\text { - pesquisas em diversos países por meio da Organização Internacional } \\
\text { do Trabalho - OIT, de cujo Programa de Emprego e Urbanização foi } \\
\text { membro diretor. }\end{array}$ \\
\hline $\begin{array}{c}\text { 1978-2001: } \\
\text { Milton Santos e } \\
\text { o planejamento } \\
\text { urbano e regional } \\
\text { no Brasil }\end{array}$ & $\begin{array}{l}\text { - Realização de consultorias na área do planejamento urbano e regional: } \\
\text { - para a Secretaria de Economia e Planejamento do Estado de São Paulo } \\
\text { e a Empresa Paulista de Planejamento Metropolitano - EMPLASA (1977- } \\
\text { 78). } \\
\text { - para a Secretaria de Planejamento do Território Federal de Rondônia } \\
\text { (1979). } \\
\text { - Atuação como Professor Convidado na Faculdade de Arquitetura e } \\
\text { Urbanismo da Universidade de São Paulo - FAU/USP (1978-82). } \\
\text { - Fundação do Laboratório de Geografia Política e Planejamento } \\
\text { Territorial e Ambiental - LABOPLAN, do Departamento de Geografia } \\
\text { da USP (1987). } \\
\text { - Atuação como representante da Sociedade Brasileira para o Progresso da } \\
\text { Ciência (SBPC) em audiência pública da Subcomissão da Questão Urbana } \\
\text { e Transporte da Assembleia Nacional Constituinte (1987). } \\
\text { - Presidência da Associação Nacional de Pós-Graduação e Pesquisa em } \\
\text { Planejamento Urbano e Regional - ANPUR (1991-93). } \\
\text { - Coordenação da Área de Arquitetura e Urbanismo da Fundação de } \\
\text { Amparo à Pesquisa do Estado de São Paulo - FAPESP (1991-94). }\end{array}$ \\
\hline
\end{tabular}

Fontes: Arquivo IEB/USP (2019), Brasil (1987), e Santos (1971, 1999a, 2001a).

Elaboração: Gabriel Leite. 
Ademais, uma apreciação da produção acadêmica de Milton Santos no decorrer dos três períodos considerados deixa ver um intelectual que sempre esteve atento aos grandes temas que animaram o planejamento urbano e regional desde meados do século passado ao início do atual (Quadro 2). No primeiro período, coincidente com o auge do nacional-desenvolvimentismo e da construção e consolidação de ideias e práticas de planificação econômica, regional e urbana no Brasil (IANNI, 1986), estavam no cerne das preocupações de Milton Santos as possibilidades de aplicação da ciência moderna, notadamente da Geografia, no planejamento do desenvolvimento de uma região periférica do Nordeste brasileiro, em situação de heterogeneidade estrutural frente ao CentroSul urbano-industrial.

No segundo período, na esteira do movimento de crítica radical à planificação, que ganhou força a partir dos anos 1970, foram os desafios e as consequências das ideias e práticas de planejamento nos países do Terceiro Mundo que passaram ao primeiro plano da obra miltoniana. Por fim, no terceiro período, caracterizado por importantes reorientações do sistema políticoeconômico brasileiro a partir da década de 1980, predominaram na produção do autor as reflexões sobre o papel - efetivo e potencial - do planejamento urbano e regional no contexto da redemocratização, da globalização e da reestruturação do território nacional.

Quadro 2 - Milton Santos e o planejamento urbano e regional: principais temas

\begin{tabular}{|c|l|}
\hline Períodos & \multicolumn{1}{c|}{ Principais temas } \\
\hline $\begin{array}{c}\text { 1956-1964: } \\
\begin{array}{c}\text { Milton Santos e o } \\
\text { planejamento urbano e } \\
\text { regional na Bahia }\end{array}\end{array}$ & $\begin{array}{l}\text { - As aplicações e contribuições da Geografia para o planejamento } \\
\text { urbano e regional. }\end{array}$ \\
$\begin{array}{c}\text { - As dimensões econômicas, sociais e espaciais da dependência e do } \\
\text { subdesenvolvimento no Estado da Bahia. } \\
\text { - O planejamento e o desenvolvimento econômico e urbano- } \\
\text { regional na Bahia. }\end{array}$ \\
$\begin{array}{c}\text { Milton Santos e o } \\
\text { planejamento urbano } \\
\text { e regional no Terceiro } \\
\text { Mundo }\end{array}$ & $\begin{array}{l}\text { - As ideologias, as funções e os desdobramentos das teorias e das } \\
\text { práticas de planificação no Terceiro Mundo. }\end{array}$ \\
\hline $\begin{array}{c}\text { A construção de alternativas ao planejamento capitalista do } \\
\text { espaço urbano e regional nos países subdesenvolvidos. }\end{array}$ \\
$\begin{array}{c}\text { Milton Santos e o } \\
\text { planejamento urbano e } \\
\text { regional no Brasil }\end{array}$ & $\begin{array}{l}\text { A redemocratização, o território e a cidadania no Brasil. } \\
\text { reestruturação do território brasileiro. }\end{array}$ \\
$\begin{array}{l}\text { - Os desafios e as possibilidades da renovação do planejamento } \\
\text { urbano e regional no período da globalização. }\end{array}$ \\
\hline
\end{tabular}

Fontes: Santos (1959a, 1964, 1986, 1993a, 2007, 2014). Elaboração: Gabriel Leite. 
Ao longo dos períodos identificados, no exercício das atividades técnicocientíficas e político-administrativas arroladas no Quadro 1 e na reflexão sobre os temas assinalados no Quadro 2, Milton Santos contribuiu ativamente para a construção do campo do planejamento urbano e regional. Para fins de sistematização, propomos que esse engajamento pode ser analisado, grosso modo, a partir de três principais contribuições do geógrafo em referência, quais sejam: a) a construção de um projeto de desenvolvimento regionalista; b) as críticas e alternativas ao planejamento urbano e regional no Terceiro Mundo; e c) a proposição de um novo planejamento urbano e regional. Na próxima seção, trataremos da contextualização e da explicitação dos conteúdos analíticos e propositivos de cada uma dessas contribuições.

\section{UM LEGADO PARA O PLANEJAMENTO URBANO E REGIONAL: AS CONTRIBUIÇÕES MILTONIANAS EM PERSPECTIVA}

Vimos até aqui que muitas foram as interseções entre a trajetória de Milton Santos e a do planejamento urbano e regional. Ainda resta saber, no entanto, o significado que tiveram para uma e para outra. Afinal, o engajamento no campo do planejamento teve importância no desenvolvimento das principais contribuições teóricas miltonianas? E, por outro lado, foram aquelas interseções relevantes para o próprio campo em referência? São essas questões que procuraremos responder a partir de uma análise das contribuições que constituem o que estamos identificando como um legado miltoniano para o planejamento urbano e regional.

\subsection{A CONSTRUÇÃO DE UM PROJETO DE DESENVOLVIMENTO REGIONALISTA}

Não tem sido suficientemente lembrada a participação de Milton Santos no profícuo ciclo de ideias e práticas de planejamento urbano e regional que teve lugar no Brasil na década de 1950 e na primeira metade dos anos 1960. Foi durante esse período, historicamente coincidente com o auge do desenvolvimentismo, que o referido geógrafo integrou a primeira tecnoestrutura de planejamento em nível estadual no país e, nessa condição, contribuiu com a elaboração de um projeto de futuro para a Bahia.

Era esse projeto, ele próprio, desenvolvimentista? É certo que nele se fizeram presentes aquelas ideias-força que, segundo Fonseca (2014), constituem o núcleo do desenvolvimentismo, quais sejam, a existência de um projeto deliberado, formulado e/ou executado por um governo; a intervenção consciente 
e determinada do Estado para viabilizá-lo; e a industrialização como caminho para acelerar o crescimento econômico, a produtividade e a difusão do progresso técnico. Acrescente-se a isso o fato de que a tecnoestrutura de planejamento estadual da qual Milton Santos participou, entre 1959 e 1964, havia sido idealizada por Rômulo Almeida, um dos mais eminentes economistas desenvolvimentistas do país ${ }^{6}$. Em avaliação retrospectiva dessa experiência, o próprio geógrafo diria que:

é esta última ideologia [a do desenvolvimento] que leva à criação de organismos como o Instituto de Economia e Finanças, mais tarde a Comissão de Planejamento Econômico (CPE). Até os anos 60, essa ideologia reunia diversas gamas de homens progressistas e de boa vontade, e que, de certo modo, se opunham à ideologia conservadora. Eles pensavam, através de um discurso desenvolvimentista, poder mudar a face da Bahia, inclusive através de um certo tipo de industrialização (SANTOS, 1987, p. 26).

Em que pese essa influência desenvolvimentista, seria um equívoco olvidar as especificidades que distinguiram o pensamento miltoniano no âmbito do ciclo de ideias e práticas sobre o planejamento urbano e regional nos anos 1950 e 1960. A primeira delas diz respeito à própria formação disciplinar de Milton Santos - um geógrafo - no âmbito de um campo do conhecimento que, à época, era predominantemente assunto de economistas, engenheiros, arquitetos e urbanistas. Um dos fundadores do primeiro centro de Geografia Aplicada no Brasil, o Laboratório de Geomorfologia e Estudos Regionais da Universidade da Bahia, Santos foi grande defensor da contribuição da ciência geográfica para a fundamentação do planejamento em um conhecimento mais sólido da totalidade das inter-relações e solidariedades que compõem o espaço urbano e regional:

por isso, [a geografia] está destinada a exercer papel sempre mais importante, junto à administração, na medida em que os homens de gôverno (sic) se forem apercebendo de que, assim como é estultície realizar obras sem planejamento, é igualmente estupidez empreender planejamentos sem a visão global dos fatos e da área em que se localizam, implicação espacial dos problemas que é o ponto de vista mesmo da geografia (SANTOS, 1959a, p. 100).

\footnotetext{
$6 \quad$ No cargo de Secretário da Fazenda da Bahia (1955-1959), Rômulo Almeida, com a experiência que adquirira na assessoria econômica do segundo governo Vargas, implementou o primeiro sistema estadual de planejamento no Brasil. Conforme esquematizamos no Quadro 1, entre 1963 e 1964, Milton Santos foi presidente do órgão mais importante desse sistema, a CPE, encarregada da elaboração de projetos econômicos, urbanos e regionais fundamentados nas pesquisas de instituições universitárias, notadamente o Instituto de Economia e Finanças e, a partir de 1959, o Laboratório de Geomorfologia e Estudos Regionais; este último também dirigido por Santos entre 1959 e 1964.
} 
Não menos relevante foi o fato de Milton Santos ter pensado o planejamento urbano e regional a partir de uma realidade socioespacial diferente daquela que se apresentava no Sudeste do país. Na Bahia, não se tratava de uma moderna economia urbano-industrial que internalizara os centros de decisão (FURTADO, 1976), mas de uma base econômica agroexportadora dependente e comandada remotamente (SANTOS, 1964). Também não se colocava a problemática da industrialização acelerada, produtora da metrópole "gigante" (FELDMAN, 2014), mas sim a da "macrocefalia" de uma metrópole "colonial", dominada pelas atividades de intermediação comercial e financeira e de especulação, e equipada com um insuficiente e frágil parque industrial (SANTOS, 1956, 1959b).

Tampouco se presenciava uma região, como a paulista, que acompanhara e se beneficiara da modernização da metrópole, com uma agricultura precocemente mecanizada e servida por uma densa rede urbana e viária, mas sim um vasto interior rural empobrecido, internamente desarticulado, pontilhado de aglomerações incipientes em número e centralidade, e onde a metrópole não se fazia sentir senão como exutório dos produtos de uma agricultura regional cujos lucros pouco lhe retornavam (SANTOS, 1964, 2008a).

Portanto, o que se apresentava na Bahia era uma situação de heterogeneidade estrutural em relação ao Sudeste brasileiro, um caráter de extrema dependência da economia e da organização do espaço; problema que Santos (1964) pensava estar na raiz da pobreza e do subdesenvolvimento naquele estado. Essa consciência da particularidade socioespacial, revelada por suas pesquisas no território baiano, também imprimiu especificidades no pensamento miltoniano sobre o planejamento do desenvolvimento, a expressar o que poderíamos denominar de um desenvolvimentismo regionalista ${ }^{7}$ (FERNANDES, 2011).

Essas especificidades podem ser observadas nas orientações e propostas de intervenção que constituíram o projeto miltoniano de desenvolvimento econômico, regional e urbano para a Bahia (Quadro 3), revelador de uma visão abrangente das dimensões sociais, econômicas e espaciais da dependência, do subdesenvolvimento e da pobreza.

\footnotetext{
O termo "desenvolvimentismo regionalista" foi utilizado por Fernandes (2011) para se referir às particularidades do discurso desenvolvimentista na Amazônia, durante as décadas de 1940 e 1950. No presente artigo, empregamos esse mesmo termo para enfatizar a existência de particularidades do pensamento miltoniano no período em tela em relação ao pensamento desenvolvimentista nacional e internacional, sem com isso sugerir a existência de similaridades com a formação discursiva que se fez presente entre os intelectuais da região amazônica.
} 
Quadro 3 - O projeto miltoniano de desenvolvimento econômico, regional e urbano para a Bahia: elementos, orientações gerais e propostas de intervenção

\begin{tabular}{|c|c|}
\hline & ações gerais e propostas de intervenção \\
\hline $\begin{array}{l}1 \\
\text { Uma política } \\
\text { agrária }\end{array}$ & $\begin{array}{l}\text { - Redução da dependência externa e provimento de um sistema defensivo da } \\
\text { agricultura baiana, incluindo políticas de preços mínimos e estímulos a melhores } \\
\text { condições de comercialização para os produtores. } \\
\text { - Criação de mecanismos para a formação e a retenção de capital indispensável } \\
\text { à melhoria técnica da própria lavoura e à transformação e diversificação da } \\
\text { estrutura econômica. } \\
\text { - Reforma da estrutura fundiária para promoção de um uso mais racional } \\
\text { do espaço e de mudanças econômicas com repercussões na distribuição, nas } \\
\text { atividades e no bem-estar da população. }\end{array}$ \\
\hline $\begin{array}{l}2 \\
\text { Uma indus- } \\
\text { trialização en- } \\
\text { dogenamente } \\
\text { orientada }\end{array}$ & $\begin{array}{l}\text { - Estímulo à transformação da estrutura econômica estadual por meio de } \\
\text { mecanismos, como o Fundo de Desenvolvimento Agroindustrial (FUNDAGRO) } \\
\text { e outros, que evitem a drenagem das poupanças regionais e orientem a aplicação } \\
\text { desses capitais no setor industrial, preferencialmente naquelas indústrias de } \\
\text { médio porte e de bens de consumo popular, mais capazes de multiplicar os } \\
\text { efeitos cumulativos e de aumentar a margem de emprego no próprio estado. }\end{array}$ \\
\hline $\begin{array}{c}3 \\
\text { Um } \\
\text { planejamento } \\
\text { metropolitano }\end{array}$ & $\begin{array}{l}\text { plano de localização industrial, código de obras, r } \\
\text { social, mecanismos de controle da especulação } \\
\text { baseados no conhecimento prévio das dinâm } \\
\text { possibilidades efetivas de orientá-las segundo as n } \\
\text { - Aprimoramento do papel metropolitano por mei } \\
\text { industrial e dos transportes, do aproveitamento c }\end{array}$ \\
\hline $\begin{array}{l}4 \\
\text { Uma ação } \\
\text { regional }\end{array}$ & $\begin{array}{l}\text { rios } \\
\text { lica } \\
\text { do } \\
\text { u. }\end{array}$ \\
\hline $\begin{array}{l}5 \\
\text { Uma } \\
\text { integração } \\
\text { interna }\end{array}$ & s sub-regiões entre si, perm \\
\hline $\begin{array}{l}\text { no } \\
\text { to }\end{array}$ & $\begin{array}{l}\text { listas } \\
\text { undo } \\
\text { das }\end{array}$ \\
\hline $\begin{array}{l}7 \\
\text { Uma reforma } \\
\text { tributária }\end{array}$ & $\begin{array}{l}\text { rgas fiscais e a repartição das rendas, de } \\
\text { alal e possibilitar investimentos em obras } \\
\text { naquelas porções do território onde os } \\
\text { res. }\end{array}$ \\
\hline \begin{tabular}{c|}
8 \\
Uma nova \\
regionalização
\end{tabular} & $\begin{array}{l}\text { - Aplicação adaptada de métodos de avaliação da centralidade urbana para a } \\
\text { elaboração de uma regionalização do território baiano baseada nas zonas de } \\
\text { influência comercial das principais cidades regionais. }\end{array}$ \\
\hline $\begin{array}{l}9 \\
\text { Um } \\
\text { planejamento } \\
\text { horizontal } \\
\text { coordenado }\end{array}$ & $\begin{array}{l}\text { - Proposição de um planejamento que parta das necessidades e prioridades } \\
\text { regionais, a serem atendidas pela coordenação interfederativa da ação } \\
\text { pública em Conselhos Estaduais de Planejamento e Conselhos Regionais de } \\
\text { Desenvolvimento. }\end{array}$ \\
\hline
\end{tabular}

Fontes: Santos (1956, 1958, 1959a, 1959b, 1959c, 1959d, 1964, 1965, 2004, 2008a). Elaboração: Gabriel Leite. 
As orientações e propostas sumariadas no Quadro 3 expressam uma visão integrada das problemáticas socioeconômicas, urbanas e regionais da Bahia dos anos 1950 e 1960, coerente com a defesa de um planejamento fundamentado no conhecimento prévio da "profunda correlação entre o que se passa dentro da cidade e o que ocorre na região de que é cabeça e a economia externa a que se liga” (SANTOS, 1959a, p. 106). Esse enfoque nas correlações que, para o autor, constituía o papel dos geógrafos nas equipes de planejamento, é bem evidente no tratamento que conferiu aos problemas da metrópole soteropolitana e da sua região, integrando as duas abordagens que, segundo Feldman (2014), se faziam presentes no pensamento urbanístico brasileiro da década de 1950 - aquela que propunha uma escala propriamente metropolitana de planejamento e aquela outra que via a metrópole concentrada como questão a ser enfrentada na escala regional; correspondentes, respectivamente, ao planejamento metropolitano e à ação regional descritos no Quadro 3.

Ademais, vale notar que, se por um lado o projeto miltoniano ia de encontro ao conservadorismo da economia agroexportadora baiana - cujo caráter dependente prejudicava qualquer esforço autônomo de planejamento e mantinha a posição de Salvador enquanto metrópole de intermediação comercial e financeira, incapacitada de manter para com a sua região relações outras que não as de espoliação -, por outro lado também não ia ao encontro dos interesses expansionistas do capital monopolista do Centro-Sul do país.

Isso fica evidente na proposta de uma industrialização endógena, a ser fomentada por fundos próprios e por planos de localização industrial que, na visão de Santos (1987, p. 26), "manifestavam uma oposição [...] aos projetos grandiosos, mas extrovertidos, da SUDENE" ${ }^{8}$, priorizando fábricas de médio porte e de bens de consumo popular, para as quais aquela superintendência, "preocupada com a grande industrialização, não voltava a sua atenção". Foi nesse mesmo sentido que se realizaram estudos para a criação de um banco baiano de desenvolvimento que pudesse complementar a ação mais geral do Banco do Nordeste por meio de visões micro ou meso do território estadual (SANTOS, 2004).

Partícipe dessa original experiência de planejamento ocorrida na Bahia - tanto a partir de dentro da Universidade, enquanto diretor do Laboratório

\footnotetext{
Trata-se da Superintendência de Desenvolvimento do Nordeste, criada em 1959 e considerada um marco da consolidação do planejamento regional brasileiro. $\mathrm{Na}$ interpretação de Santos (1987), a sistemática de incentivos fiscais adotada por essa superintendência e a concretização de grandes projetos na Bahia (Centro Industrial de Aratu, Polo Petroquímico de Camaçari e Centro Administrativo da Bahia), sobretudo no período pós-1964, foram sintomáticas da transição da ideologia do desenvolvimento, que por vezes comportava preocupações teleológicas e generosas, para uma ideologia do crescimento, quase que exclusivamente voltada para as grandes indústrias e outras atividades modernas.
} 
de Geomorfologia e Estudos Regionais, quanto na própria estrutura do Estado, na condição de presidente da CPE -, Milton Santos contribuiu decisivamente para a construção de um projeto de desenvolvimento que, a despeito de ter sido descontinuado a partir de 1964, aparece-nos hoje como testemunho de que os rumos da modernização no Brasil também foram disputados por perspectivas alternativas, mais críticas em relação às suas consequências sociais e mais enraizadas nas particularidades socioespaciais e culturais das diversas regiões do território brasileiro.

\subsection{AS CRÍTICAS E ALTERNATIVAS AO PLANEJAMENTO URBANO E REGIONAL NO TERCEIRO MUNDO}

O período do exílio de Milton Santos, entre 1965 e 1977, foi também aquele em que esteve inserido no circuito internacional resultante do processo de profissionalização e institucionalização do campo do desenvolvimento. Era um momento em que, já consolidado o constructo intelectual do Terceiro Mundo, difundia-se mundialmente um sistema de organismos e instituições internacionais e nacionais, universidades e centros de pesquisa, ciências e subcampos disciplinares, programas e experts, todos empenhados na produção de ideias e práticas concernentes ao subdesenvolvimento e à pobreza.

Foi nessa experiência que esteve enraizada aquilo que reconhecemos como uma segunda contribuição miltoniana para o planejamento urbano e regional. Segundo o próprio autor, a sua crescente insatisfação com os modelos dominantes e amplamente difundidos por meio daquele circuito internacional levaram-no a "repensar a geografia do Terceiro Mundo" (SANTOS, 2004, p. 19), um esforço que incluiu a crítica sistemática àquelas teorias que:

em um primeiro momento, julgávamos hostis aos interesses dos países subdesenvolvidos e mais recentemente nos apareceram como o instrumento privilegiado da difusão do capital, tanto para agravar o subdesenvolvimento como para manter a estrutura de classes e assegurar a expansão da pobreza. [...] Tais teorias, postas sem recato maior ao serviço exclusivo do capital e sobretudo do capital internacional, mostraramse indiferentes à sorte da grande maioria das coletividades nacionais do Terceiro Mundo (SANTOS, 2007, p. 11).

Segundo Santos (2007), o exame crítico das proposições e das práticas de planejamento no Terceiro Mundo possibilitou o entendimento de sua funcionalidade para uma das principais tendências estruturais do sistema capitalista no período tecnológico, qual seja, a transformação progressiva das 
relações comerciais entre países cêntricos e periféricos em operações internas das grandes empresas (FURTADO, 1976). Estas, que retiram sua força das técnicas de coordenação oligopólica, passaram a expandir suas operações para a periferia capitalista no pós-Segunda Guerra Mundial, desenhando uma nova divisão internacional do trabalho que já se mostrava evidente na segunda metade da década de 1960.

A relevância da contribuição de Milton Santos para o entendimento desse processo - por meio do qual os países periféricos passaram a assumir crescente importância para as grandes empresas dos países cêntricos - esteve em elucidar o papel decisivo que nele desempenhou o planejamento, sem o qual "teria sido impossível atingir-se uma intromissão tão rápida e brutal do grande capital nessas nações" (SANTOS, 2007, p. 13).

Nessa perspectiva de interpretação, foram as necessidades do capitalismo cêntrico, notadamente aquelas dos oligopólios internacionais, que demandaram a produção de uma ciência do espaço econômico comprometida com a elaboração de ideias e teorias voltadas para "justificar cientificamente arranjos espaciais que promovem a expansão capitalista” (SANTOS, 2007, p. 22). Por essa razão, o autor defendeu ser necessária a crítica sistemática dessas formulações que fundamentavam grande parte do planejamento urbano e regional nos países subdesenvolvidos (Quadro 4).

As formulações sumariadas no Quadro 4 e as práticas a que estiveram associadas nos países periféricos constituíram, em conjunto, aquilo que Santos (2007) denominou de planejamento do subdesenvolvimento e da dependência. Isso porque concorreram, de forma mais ou menos consciente, para a perpetuação e o aprofundamento desses dois fenômenos, não apenas em suas manifestações econômicas, mas também em suas projeções espaciais (SANTOS, 2013a), definindo espaços derivados, periféricos, seletivos, descontínuos, incompletamente organizados, não integrados e instáveis.

Nesse contexto, e concordando com Furtado (1976, p. 87) que "a transição do subdesenvolvimento para o desenvolvimento é dificilmente concebível, no quadro da dependência", Santos (2008b) propôs que o primeiro passo, em um projeto comprometido com a justiça social, deveria ser a utilização do poder mediador do Estado para modificar as relações dependentes das formações socioespaciais periféricas com o sistema internacional, inclusive com as internalizações deste último na forma das empresas multinacionais. 


\section{Quadro 4 - As críticas de Milton Santos à economia espacial}

\begin{tabular}{|c|c|}
\hline Ideias e teorias & Críticas de Milton Santos \\
\hline $\begin{array}{l}\text { Polos de crescimento } \\
\text { Matriz locacional } \\
\text { Desconcentração } \\
\text { concentrada } \\
\text { Urbanização } \\
\text { deliberada }\end{array}$ & $\begin{array}{l}\text { - As teorias dos polos de crescimento e da matriz locacional foram } \\
\text { amplamente operacionalizadas na forma de políticas regionais de } \\
\text { desenvolvimento urbano-industrial, que na América Latina também se } \\
\text { desdobraram nas teses da desconcentração concentrada e da urbanização } \\
\text { deliberada. Os problemas e as limitações que enfrentaram estiveram } \\
\text { relacionados às especificidades das regiões periféricas que foram objetos } \\
\text { de planejamento: } \\
\text { - a descontinuidade entre os tipos e níveis das demandas das atividades } \\
\text { do circuito superior da economia e aqueles das atividades preexistentes } \\
\text { na região leva a uma situação de não integração que bloqueia os efeitos } \\
\text { multiplicadores e em cadeia. } \\
\text { - a instalação de atividades modernas pouco alinhadas ao perfil das } \\
\text { atividades regionais conduz à criação de enclaves urbanos caracterizados } \\
\text { pela dissociação entre a dinâmica econômica da cidade (fortalecida) e a sua } \\
\text { dinâmica regional (enfraquecida). } \\
\text { - os objetivos anunciados de desconcentração demográfica e econômica } \\
\text { no território nacional entram em contradição com o privilégio conferido } \\
\text { a um circuito da economia cujas características favorecem relações } \\
\text { extrovertidas em benefício das metrópoles econômicas no país e } \\
\text { no exterior, e em detrimento dos níveis de emprego e bem-estar da } \\
\text { população local. } \\
\text { - a periferia não aparece como uma função da distância em relação ao } \\
\text { polo ou ao centro de uma matriz locacional; pelo contrário, ela também } \\
\text { é produzida nas proximidades e no interior dessas áreas "dinâmicas", } \\
\text { animando um circuito econômico alternativo - o circuito inferior } \\
\text { enraizado na cidade e na sua região. } \\
\text { - a capacidade efetiva de planejamento a partir dos centros de decisão } \\
\text { locais e regionais fica comprometida, posto que a política das grandes } \\
\text { empresas é elaborada em função de suas próprias operações internas e } \\
\text { desde centros de decisão exógenos à cidade e à região. }\end{array}$ \\
\hline Lugares centrais & $\begin{array}{l}\text { - Não é apenas o circuito superior da economia que define as áreas de } \\
\text { influência das cidades nos países subdesenvolvidos. A presença de } \\
\text { periferias geográficas e socioeconômicas em todo o território, inclusive nas } \\
\text { áreas mais "dinâmicas", também garante ao circuito inferior a capacidade } \\
\text { de organização do espaço nos diferentes níveis hierárquicos da rede de } \\
\text { lugares centrais: } \\
\text { - nas metrópoles, o circuito superior alcança grandes extensões, enquanto } \\
\text { o denso circuito inferior tem sua influência restrita aos limites da própria } \\
\text { aglomeração. } \\
\text { - nas cidades intermediárias, o alcance do circuito superior assume certa } \\
\text { expressão e o do circuito inferior confunde-se com a área de influência } \\
\text { regional da aglomeração. } \\
\text { - nas cidades locais, o circuito inferior dispõe de um alcance relativamente } \\
\text { extenso, enquanto para o circuito superior o alcance é apenas hipotético } \\
\text { (exceção feita àquelas cidades preparadas para receber modernas } \\
\text { instalações industriais). }\end{array}$ \\
\hline
\end{tabular}

9 Trata-se do circuito econômico das grandes empresas modernas cujas operações baseadas na elevada intensidade tecnológica e capitalista e pautadas em um quadro de referência nacional ou internacional criam descontinuidades no aparelho produtivo e reforçam as seletividades geográficas e as disparidades entre os níveis de renda das camadas populacionais (SANTOS, 2008b).

10 Trata-se de um circuito econômico animado por aquelas atividades que pouco ou nada absorveram as modernizações tecnológicas e organizacionais, bem como por aqueles segmentos populacionais de menores níveis de renda e de diversificação do consumo (SANTOS, 2008b). 


\begin{tabular}{|c|c|}
\hline Base de exportação & $\begin{array}{l}\text { - A teoria entende que a expansão da base de exportação pode ser o } \\
\text { principal fator de indução do crescimento econômico regional, do } \\
\text { desenvolvimento de economias externas, da urbanização e, eventualmente, } \\
\text { da industrialização. Essa ideia, segundo a qual as atividades básicas } \\
\text { (exportadoras) induzem o desenvolvimento das atividades não básicas } \\
\text { (voltadas para o consumo local), encontra limitações e insuficiências nos } \\
\text { países subdesenvolvidos: } \\
\text { - a promoção de culturas comerciais para exportação, geradoras das } \\
\text { divisas requeridas pelos modelos de desenvolvimento dominantes, } \\
\text { ocorreu em detrimento das culturas alimentares que servem de base para } \\
\text { relações mutuamente fortalecedoras entre as cidades e as suas regiões } \\
\text { circundantes. } \\
\text { - a distinção entre atividades "city forming" (exportadoras) e "city serving" } \\
\text { (voltadas para o consumo local) não é tão evidente, posto que as primeiras } \\
\text { exigem a colaboração de atividades locais e as segundas frequentemente } \\
\text { dependem de imputs vindos do exterior. } \\
\text { muito mais proveitoso para o planejamento seria distinguir, no interior } \\
\text { do meio urbano, as atividades "nation building" ou "region building" das } \\
\text { atividades voltadas para fora. }\end{array}$ \\
\hline $\begin{array}{l}\text { lo } \\
\text { lvimento } \\
\text { ico regional }\end{array}$ & $\begin{array}{l}\text { - A teoria justificou iniciativas dedicadas a preparar as precondições para } \\
\text { o take-off ("decolagem"), entendido como a etapa na qual a economia } \\
\text { regional sofre uma inflexão para o desenvolvimento autossustentado. } \\
\text { A necessidade de coordenação de volumosos investimentos públicos e } \\
\text { privados no provimento do social overhead capital necessário à "decolagem" } \\
\text { conduz a uma tendência de planejamento precipuamente voltada para a } \\
\text { intervenção sobre as formas espaciais preexistentes e para a introdução } \\
\text { de novos objetos mais funcionais à expansão capitalista: } \\
\text { - os pacotes de modernização agrícola, os grandes projetos e as iniciativas } \\
\text { de "renovação" urbana desarticulam formas de organização preexistentes } \\
\text { e abrem caminho para a modernização capitalista, instalando nexos } \\
\text { de dependência e consagrando concentrações, imobilizações, } \\
\text { irreversibilidades e indivisibilidades. }\end{array}$ \\
\hline Teorias locacionais & $\begin{array}{l}\text { - A localização das atividades econômicas no território tem relação direta } \\
\text { com a estrutura de capital presente em cada país, e esta varia em função } \\
\text { da maior ou menor participação nacional no comércio internacional. } \\
\text { Por isso, as teorias locacionais clássicas que lançam mão de categorias } \\
\text { econômico-espaciais absolutas e restritas à escala local tomam como } \\
\text { causa aquilo que é apenas condição da localização e, desse modo, } \\
\text { justificam arranjos espaciais adequados à expansão capitalista: } \\
\text { - as economias externas não explicam, mas antes são explicadas pelas } \\
\text { decisões locacionais dos maiores capitais, tanto mais discricionárias } \\
\text { e flexíveis quanto maior a capacidade de coordenação oligopólica e } \\
\text { financeira e de acionamento de dispositivos políticos. } \\
\text { as economias de escala dizem mais respeito à economia política que à } \\
\text { localização. } \\
\text { - as economias de aglomeração são seletivamente utilizadas pelas maiores } \\
\text { empresas e as deseconomias não as afetam de fato, pois são transferidas } \\
\text { para o Estado, as firmas menores e a população. }\end{array}$ \\
\hline Difusão de inovações & $\begin{array}{l}\text { - Instrumentalizada para fins mercadológicos e ideológicos, a teoria } \\
\text { serviu a operações nos domínios do consumo e da produção: } \\
\text { - a formulação de estratégias para difusão social e espacial de padrões } \\
\text { de consumo importados dos países cêntricos e programados pelas } \\
\text { subsidiárias das grandes empresas. } \\
\text { - a associação com as teorias dos lugares centrais e dos polos de } \\
\text { crescimento para justificação de projetos de desconcentração que, na } \\
\text { verdade, reforçam as concentrações cumulativas. }\end{array}$ \\
\hline
\end{tabular}

Fontes: Santos (1979, 2007, 2008b). Elaboração: Gabriel Leite. 
No arrefecimento da situação de dependência, Milton Santos via a possibilidade de um novo planejamento. No que diz respeito ao consumo, tratar-se-ia de passar dos fluxos aos estoques (SANTOS, 1980), isto é, da introdução contínua de novos produtos com base em padrões importados para a difusão de uma cesta de bens e serviços de consumo popular, já existentes, mas insuficientemente acessados. Como a estrutura do consumo guarda relação com a intensidade de tecnologia e de capital no aparelho produtivo (FURTADO, 1976), também a estrutura de produção conheceria mudanças, inclusive porque o esforço industrial, mais endogenamente orientado, poderia empregar um fator bastante subutilizado no período tecnológico, o trabalho humano (SANTOS, 2008b). Nessas novas condições de consumo, de produção e de emprego, não somente as disparidades de renda seriam menos expressivas, como também a distância entre os circuitos da economia diminuiria, o circuito superior tornandose menos superior e o circuito inferior, menos inferior (SANTOS, 2007).

Mas não seria apenas a economia a ser coordenada segundo objetivos sociais. Isso porque, mesmo quando avanços importantes são feitos nas estruturas econômicas e políticas, a manutenção dos padrões capitalistas de organização espacial pode continuar a perpetuar desigualdades e pode, mesmo, chegar a ser o veículo de (re)introdução do nexo de dependência no interior de uma formação socioespacial, conforme observou Santos (1978) para o caso da Tanzânia. Por essa razão, o autor defendeu que, tão importante quanto as políticas do consumo, da produção e do emprego, é a proposição de um novo planejamento do espaço cujos objetivos principais sejam a "eliminação das injunções que se criaram através de uma organização capitalista do espaço regional e urbano" (SANTOS, 1980, p. 41) e a construção das condições espaciais favoráveis à liberação, à igualdade e à dignidade humanas.

Também nesse caso a diminuição ou a supressão da dependência externa coloca-se como condição necessária. Na avaliação de Santos (2008b), a liberação da necessidade de grandes capitais e a nova estrutura produtiva, mais consentânea com as técnicas locais e mais solidária com os perfis regionais de consumo, permitiriam, graças à redução da escala e da indivisibilidade dos investimentos, a desconcentração das atividades econômicas no território. Seria essa uma "modernização nacional regionalizada", subordinada às demandas nacionais e regionais, diferente da modernização de caráter internacional. Por outro lado, o Estado, liberado de seus dispendiosos compromissos com o circuito superior, seria mais capaz de realizar os necessários investimentos sociais nas periferias geográficas e socioeconômicas. 
Para Santos (2007), esses dois movimentos fortaleceriam a rede de cidades intermediárias e locais, que passariam, enfim, a dispor de um maior número de bens e serviços públicos e de um continuum de atividades comerciais, industriais e de serviços, em nada semelhante à economia segmentada em circuitos descontínuos e hierarquizados. Dessa maneira, a dinâmica econômica das cidades, animada por verdadeiras atividades region building, não mais seria dissociada de sua dinâmica regional (SANTOS, 2008b), o que acarretaria importantes efeitos multiplicadores sociais e econômicos nos respectivos locais.

Apenas nessa posição de fortalecedor das relações cidade-região e das condições de cidadania das populações regionais, poder-se-ia falar, não de um único polo de crescimento, mas daquilo a que Santos (2007) se referiu como um sistema de polos de desenvolvimento social e econômico, também importantes para o redirecionamento dos fluxos migratórios e para o arrefecimento das concentrações cumulativas e das "macrocefalias" urbanas.

Esse delineamento geral de uma planificação espacial integrada a um projeto de superação da dependência e do subdesenvolvimento representou, na trajetória miltoniana, o ponto de partida de um esforço de renovação do planejamento urbano e regional; esforço este que se inicia pelo trabalho de crítica, mas que deve se encaminhar, conforme exortou Santos (2007, p. 11), para a formulação de "alternativas válidas, fundadas na especificidade dos nossos países e preocupadas em atribuir à maioria das populações interessadas aqueles bens, serviços e valores que restituam a cada homem a possibilidade de viver dignamente".

\subsection{A PROPOSIÇÃO DE UM NOVO PLANEJAMENTO URBANO E REGIONAL}

Quando Santos (2012a) apresentou a proposta de uma Geografia Nova, esclareceu que o "novo" não é uma invenção caprichosa da mente científica, mas antes uma descoberta a que estão obrigadas todas as disciplinas sempre que as condições gerais de realização da vida experimentam importantes mudanças qualitativas. É nesse mesmo sentido que devemos entender a proposição de um novo planejamento urbano e regional (SANTOS, 1993a), aqui considerada como uma terceira contribuição miltoniana para esse campo do conhecimento.

Com a emergência de um novo sistema de variáveis, isto é, um novo período que redefine o espaço, o planejamento urbano e regional não mais pode comportar fórmulas pré-fabricadas e nem admitir a utilização de teorias historicamente superadas. Dessa premissa sustentada por Santos (1993a, p. 39), tem-se como corolário que "é na própria história contemporânea, história 
conjunta do mundo e dos lugares, que devemos nos inspirar tanto para entender os problemas, como para tentar resolvê-los".

Nesse sentido, desde finais da década de 1970 até o início dos anos 2000, em meio às grandes transformações político-econômicas e territoriais que acompanharam a inserção do Brasil na globalização, Milton Santos contribuiu continuadamente com o delineamento de caminhos de renovação para o campo do planejamento urbano e regional (Quadro 5).

Quadro 5 - A proposta miltoniana para um novo planejamento urbano e regional: principais ideias-força

\begin{tabular}{|c|c|}
\hline Ideias-força & Comentário explicativo \\
\hline $\begin{array}{c}1 \\
\text { Por um novo } \\
\text { modelo } \\
\text { cívico-territorial }\end{array}$ & $\begin{array}{l}\text { - A pobreza e as desigualdades não são produtos exclusivos de um modelo } \\
\text { econômico inigualitário e de um modelo político autoritário. Articulado a } \\
\text { estes está um modelo territorial mercantil, uma organização do território } \\
\text { criadora de situações diferenciais de acessibilidade e de mobilidade que } \\
\text { definem, para cada indivíduo, empresa e instituição, as condições objetivas } \\
\text { e subjetivas de produção, de consumo e de cidadania. Reverter esse quadro } \\
\text { requer a elaboração de um novo modelo cívico-territorial: } \\
\text { - o componente cívico está relacionado aos valores e pactos de solidariedade } \\
\text { que definem o estatuto da cidadania e que devem presidir a escolha dos } \\
\text { caminhos adotados na condução da vida coletiva. } \\
\text { - o componente territorial diz respeito à instrumentalização do território, de } \\
\text { sua organização e de sua gestão, como base de apoio de um planejamento } \\
\text { redistributivo, conducente à atribuição dos bens e serviços indispensáveis à } \\
\text { cidadania para a totalidade da população. }\end{array}$ \\
\hline $\begin{array}{c}2 \\
\text { Em busca } \\
\text { de novas } \\
\text { horizontalidades }\end{array}$ & $\begin{array}{l}\text { - As verticalidades, novos recortes espaciais do período da globalização, } \\
\text { impõem grandes desafios ao planejamento regional. Resultado do fato de que } \\
\text { a ação dos agentes hegemônicos torna-se mais espacialmente descontínua, } \\
\text { as segmentações verticais surgem para unificar, por meio da informação, } \\
\text { do controle e da regulação, os pontos do território que funcionalizam os } \\
\text { diversos momentos da produção. (Re)criam entre eles uma dependência } \\
\text { de nova natureza dos subespaços periféricos em relação aos subespaços } \\
\text { centrais. Estes últimos, onde o meio técnico-científico-informacional é } \\
\text { denso e contínuo, são as regiões do mandar; aqueles primeiros, onde esse } \\
\text { mesmo meio aparece em seletos pontos e manchas, tornam-se as regiões } \\
\text { do fazer, do fazer para os outros, porque perdem a capacidade de gestão } \\
\text { da vida regional. Para essas regiões cujas solidariedades locais são objeto de } \\
\text { uma incessante entropia comandada de longe e de cima, impõe-se a busca } \\
\text { de novas horizontalidades: } \\
\text { - criadas pelo poder político ou pelo cotidiano produtivo e interpessoal, as } \\
\text { horizontalidades são áreas de contiguidade unidas por forças agregadoras de } \\
\text { homogeneização, de aglomeração ou de coesão. Nelas, a interdependência } \\
\text { horizontal e o cotidiano homólogo engendram, por sobre as diferenças, } \\
\text { uma comunidade de interesses fundada na consciência de uma experiência } \\
\text { comum de subordinação. } \\
\text { - a produtividade econômica das horizontalidades pode dar lugar a uma } \\
\text { produtividade política quando as contingências da existência comum servem } \\
\text { de base à elaboração de um sistema amplo de reivindicações que desafiem as } \\
\text { verticalidades não controláveis pelas sociedades locais e que busquem impor } \\
\text { regulações sociais da atividade econômica. }\end{array}$ \\
\hline
\end{tabular}


3

Da racionalidade à contrafinalidade

4

A flexibilidade tropical como potencialidade

5

Um planejamento sociopolítico da cidade
- Com a globalização, a racionalidade capitalista, depois de haver penetrado diversos outros domínios da vida social, atinge também o espaço. Torna-se mais difícil planejar o que nos é próximo, na medida em que, no campo e na cidade, são instalados sistemas de objetos cujas estruturas técnico-científicoinformacionais altamente intencionais somente autorizam sistemas de ações com igual nível e natureza de intencionalidade e de racionalidade. No entanto, como esse processo de racionalização é limitado, há sempre uma produção concomitante e ilimitada de escassez e de "irracionalidade", bases da renovação do planejamento urbano e regional:

- urge a elaboração dos instrumentos de intervenção e das regras de um planejamento eficaz e aceitável na potencialização das contrafinalidades e das contrarracionalidades que se encontram, de um ponto de vista social, nas maiorias empobrecidas e nas minorias excluídas; de um ponto de vista econômico, nas atividades marginalizadas; e de um ponto de vista geográfico, nos espaços "opacos" onde a materialidade herdada autoriza tempos mais lentos e comportamentos econômicos e sociais alternativos.

- A produção do subsistema técnico-científico-informacional das metrópoles do Terceiro Mundo, rígido na sua adequação estrita às ações dos agentes hegemônicos, não se faz sem a participação decisiva de um planejamento urbano exclusivo, dedicado às tarefas do planejamento empresarial e que se confunde com a redação de um manual de investimentos. Enquanto isso, a maior parte da aglomeração, negligenciada por esse tipo de planificação, comporta uma verdadeira flexibilidade tropical em cujo tripé pode assentar um novo planejamento urbano e metropolitano:

- a economia segmentada, mas única: o planejamento precisa compreender o que é o trabalho, como e onde ele acontece nas cidades, o que pressupõe o conhecimento dos circuitos de produção, circulação, distribuição e consumo de distintos níveis de capital, tecnologia e organização que compõem uma economia segmentada, mas única.

- o meio ambiente construído: as intervenções espaciais devem ter em conta que, para a maior parte da população e das atividades, localmente enraizadas no meio geográfico, orgânicas e mantenedoras de relações de simbiose com o entorno imediato, aquilo que se faz com o meio construído urbano impacta diretamente nas suas perspectivas de futuro.

- a população compósita: a própria população, na sua diversidade, no seu movimento e na sua comunicação, é dotada de um dinamismo próprio criador de economia e riqueza social.

- Resultado da interdependência assimétrica e hierárquica dos sistemas de poder atuantes nas cidades, as teorias e as práticas do planejamento técnicoeconômico tornam-se promotoras ativas da urbanização corporativa, na qual o essencial do Capital Geral é produzido, localizado, acessado e utilizado preferencialmente para/por grandes capitais particulares que dele extraem maiores taxas de mais-valia e maior competitividade relativa. Os graves problemas socioespaciais que decorrem dessa dinâmica perversa não são, portanto, questões técnico-econômicas em sentido estrito, mas sobretudo problemáticas sociopolíticas que estão a exigir uma verdadeira política social da cidade:

- o registro das carências existentes e de suas causas próximas e gerais aparece como ponto de partida para um planejamento sociopolítico que, de um lado, se ocupe da distribuição dos recursos sociais e, de outro, consagre os instrumentos políticos de controle social, capazes de assegurar a cidadania plena. 


\begin{tabular}{|c|c|}
\hline $\begin{array}{c}\mathbf{6} \\
\text { O papel renovado } \\
\text { do saber local }\end{array}$ & $\begin{array}{l}\text { - Com as unicidades que sustentam a globalização, a universalidade torna-se } \\
\text { empírica. O mundo passa a ser mais visível e inteligível a partir dos lugares. } \\
\text { Nessas condições, o saber do expert internacional, quando se quer crítico, } \\
\text { pode tão somente fornecer os elementos de um quadro geral de reflexão, a } \\
\text { ser reformulado localmente. O discurso político eficaz é, cada vez mais, o } \\
\text { discurso do cotidiano, somente formulado pelos sábios locais: } \\
\text { - o fortalecimento da produção dos estoques de saber local e regional, únicos } \\
\text { capazes de dar a conhecer o que são as ações humanas e quais os objetos } \\
\text { indispensáveis para a realização dessas ações, torna-se algo de central para } \\
\text { a (auto)afirmação das cidades e das regiões em um mundo vertiginoso que } \\
\text { dificulta o discurso e o processo do planejamento. } \\
\text { - o saber local e o da região, também conhecedores do mundo, passam a } \\
\text { ser os mais capazes de propor o que fazer para que as cidades e as regiões } \\
\text { tornem-se mais do que lugares funcionais do todo, mais do que suportes } \\
\text { à realização das relações globais de produção, e possam participar da } \\
\text { construção do seu próprio futuro. }\end{array}$ \\
\hline $\begin{array}{c}7 \\
\text { spaço seletivo } \\
\text { paço de todos }\end{array}$ & $\begin{array}{l}\text { - As verticalidades configuram um subsistema espacial seletivo. Trata-se de } \\
\text { um conjunto de pontos descontínuos, mas interligados, que interessam à } \\
\text { ação dos macroatores, sobretudo das macroempresas. O planejamento } \\
\text { exclusivamente dedicado a esse espaço seletivo não pode ser qualificado } \\
\text { como urbano ou regional, pois lhe falta a noção de totalidade do espaço: } \\
\text { - a noção de horizontalidade permitiria o (re)encontro do planejamento } \\
\text { urbano e regional com outro subsistema espacial, o espaço banal, cuja } \\
\text { contiguidade é o fundamento das solidariedades internas entre pessoas, } \\
\text { empresas e instituições e a garantia da presença de contrarracionalidades, } \\
\text { formas de convivência e de regulação criadas a partir da relação estreita com } \\
\text { o próprio território local. } \\
\text { - a categoria analítica do território usado possibilitaria a construção de } \\
\text { políticas de baixo para cima, fundadas nos usos que as sociedades locais e } \\
\text { regionais fazem dos seus meios de vida, ao contrário das políticas de cima } \\
\text { para baixo, voltadas para um uso exclusivo e corporativo do território, que } \\
\text { as verticalidades transportam e justificam. }\end{array}$ \\
\hline $\begin{array}{c}\mathbf{8} \\
\text { Em direção a } \\
\text { uma federação de } \\
\text { lugares }\end{array}$ & $\begin{array}{l}\text { - Para contrarrestar as tendências simultaneamente centralistas e } \\
\text { desagregadoras que acossam a federação brasileira inserida de forma } \\
\text { subordinada na globalização, impõe-se uma "lugarização" da federação: } \\
\text { trata-se de uma reconstrução federativa a partir de baixo, mediante uma } \\
\text { regionalização do cotidiano que reconheça áreas locais-regionais de } \\
\text { identidade, intermediárias entre os estados e os municípios, e alçadas à } \\
\text { condição de um quarto nível político-territorial. } \\
\text { - a essas entidades territoriais caberiam as competências e os recursos para } \\
\text { propor os modos e as combinações próprias da vida local segundo a realidade } \\
\text { e os interesses concretos do cotidiano dos indivíduos, das empresas e das } \\
\text { instituições atuantes nos espaços das horizontalidades. } \\
\text { - o cidadão é o "indivíduo num lugar"; por conseguinte, a cidadania na sua } \\
\text { tríplice significação - social, econômica e política-depende da revalorização } \\
\text { e readequação do estatuto político dos lugares. }\end{array}$ \\
\hline
\end{tabular}

Fontes: Arquivo IEB/USP (2019) e Santos (1993a, 1993b, 1994, 1995, 1999b, 2000, 2001b, 2012b, 2013b, 2014). Elaboração: Gabriel Leite.

Vejamos, agora, como as ideias-força sintetizadas no Quadro 5 foram desenvolvidas em contínuo intercâmbio com o campo do planejamento urbano e regional. Ainda em 1979, quando foi contratado pela Secretaria de Planejamento do Território Federal de Rondônia para a elaboração de um 
estudo sobre a interiorização do apoio urbano nas áreas de colonização ao longo da BR-364 (Cuiabá-Porto Velho), Milton Santos pôde refletir sobre a relação entre os problemas de uma dada organização social, notadamente as desigualdades e a pobreza, e a sua organização espacial; relação esta que está na base do que viria a ser a proposição miltoniana de um novo modelo cívico-territorial. Uma das propostas de intervenção de cuja concepção Santos participou - a criação de Núcleos Urbanos de Apoio Rural (NUAR) voltados para a prestação de serviços de saúde, educação e assistência técnica e social aos assentados $^{11}$ - foi por ele considerado um projeto justo, mas que não poderia ser uma ação isolada das demais relações socioespaciais que, em conjunto, determinam a condição de cada indivíduo enquanto produtor, consumidor e cidadão (SANTOS, 1982).

Essa reflexão seria mais desenvolvida em termos teóricos durante a década de 1980, sobretudo no contexto do engajamento de Milton Santos nos debates públicos abertos pelas perspectivas da redemocratização brasileira. Encarregado de tratar da questão urbana e regional na audiência pública promovida pela Subcomissão da Questão Urbana e Transporte da Assembleia Nacional Constituinte $^{12}$ (BRASIL, 1987), o geógrafo apresentou a proposta de uma organização político-territorial cívica (Quadro 6) que poderia servir de base para um planejamento "em que as realidades locais sejam um ponto de partida para o raciocínio dos administradores, e não apenas o lugar de ações desencontradas e, por isso mesmo, estruturalmente ineficazes" (SANTOS, 2014, p. 146).

11 Informações obtidas em: a) entrevista com o Prof. Dr. Sylvio Barros Sawaya (FAU/USP) (via Skype, em 03 de maio de 2019), arquiteto e urbanista que indicou Milton Santos para o serviço de consultoria; b) mensagem de e-mail enviada pelo Prof. Dr. Silvio Rodrigues Persivo Cunha (Departamento de Economia da Universidade Federal de Rondônia) (CUNHA, 2019), economista que, à época, integrava o corpo técnico da Secretaria de Planejamento do Território Federal de Rondônia; e c) Arquivo IEB/USP (2019).

12 As subcomissões temáticas eram responsáveis pela elaboração de anteprojetos com vistas a subsidiar o Projeto de Constituição a ser entregue ao Plenário da Assembleia Nacional Constituinte. Na audiência pública mencionada, à exceção de Milton Santos, representante da SBPC, todos os demais participantes foram representantes de entidades ligadas ao Movimento Nacional pela Reforma Urbana (MNRU) (BRASIL, 1987). 
Quadro 6 - A proposição de Milton Santos para a Constituição Federal de 1988: uma organização político-territorial cívica

\begin{tabular}{|c|c|c|}
\hline Atributos & Definições & Proposições \\
\hline $\begin{array}{l}\text { Sensibilidade à } \\
\text { diferenciação } \\
\text { espacial }\end{array}$ & $\begin{array}{l}\text { Os níveis territoriais da ação pública } \\
\text { acompanham a diferenciação do } \\
\text { território nacional em várias escalas } \\
\text { geográficas. }\end{array}$ & $\begin{array}{l}\text { A criação de entidades } \\
\text { representativas sub-regionais com } \\
\text { cargos eletivos e competência } \\
\text { legislativa para propor os modos } \\
\text { próprios de regulação da vida } \\
\text { regional. }\end{array}$ \\
\hline $\begin{array}{l}\text { Escalonamento } \\
\text { temporal das ações }\end{array}$ & $\begin{array}{l}\text { A ação pública em todos os níveis } \\
\text { territoriais é discriminada segundo } \\
\text { diferentes horizontes temporais. }\end{array}$ & $\begin{array}{l}\text { O estabelecimento de cronogramas } \\
\text { de ações discriminadas em } \\
\text { horizontes temporais que denotam } \\
\text { a factibilidade das propostas e as } \\
\text { prioridades estabelecidas. }\end{array}$ \\
\hline $\begin{array}{l}\text { Instrumentalidade } \\
\text { das delimitações e } \\
\text { das competências } \\
\text { administrativas }\end{array}$ & $\begin{array}{l}\text { As delimitações, as competências } \\
\text { administrativas e legislativas e a } \\
\text { disponibilidade de recursos dos } \\
\text { níveis territoriais da ação pública } \\
\text { são instrumentais a objetivos a } \\
\text { atingir em cada escala geográfica. }\end{array}$ & $\begin{array}{l}\text { A autonomia municipal de gastos } \\
\text { em matérias que digam respeito à } \\
\text { vida cultural redefinida e à provisão } \\
\text { de bens e serviços essenciais e } \\
\text { inadiáveis. }\end{array}$ \\
\hline $\begin{array}{l}\text { Dinamicidade das } \\
\text { delimitações e } \\
\text { das competências } \\
\text { administrativas }\end{array}$ & $\begin{array}{l}\text { Os limites e as competências } \\
\text { administrativas são flexíveis para } \\
\text { atender às mudanças de objetivos } \\
\text { sociais e das localizações no } \\
\text { território. }\end{array}$ & $\begin{array}{l}\text { A revisão periódica das delimitações } \\
\text { e das competências administrativas } \\
\text { e o estabelecimento de regras } \\
\text { flexíveis de repartição territorial } \\
\text { dos recursos e dos gastos públicos. }\end{array}$ \\
\hline $\begin{array}{l}\text { Equidade da } \\
\text { distribuição social e } \\
\text { territorial dos bens e } \\
\text { serviços essenciais }\end{array}$ & $\begin{array}{l}\text { As características dos bens e } \\
\text { serviços (frequência da demanda e } \\
\text { complexidade) e as especificidades } \\
\text { do território (distâncias, fluidez, } \\
\text { faixas de densidade demográfica } \\
\text { e alcances dos núcleos) são } \\
\text { consideradas conjuntamente } \\
\text { em um planejamento espacial } \\
\text { redistributivo. }\end{array}$ & $\begin{array}{l}\text { A instrumentalização da rede } \\
\text { urbana e do sistema de transportes } \\
\text { em prol da implantação, do reforço } \\
\text { e do acesso igualitários dos/aos } \\
\text { fixos, bens e serviços essenciais à } \\
\text { cidadania. }\end{array}$ \\
\hline
\end{tabular}

Fontes: Brasil (1987) e Santos (2014). Elaboração: Gabriel Leite.

Ademais, a proposta de um planejamento urbano filosófico a ser fomentado pela presença e participação ativa de centros de estudos e pesquisas nas tecnoestruturas planejadoras, apresentada por Milton Santos como subsídio ao trato da questão metropolitana pela nova Constituição Federal brasileira ${ }^{13}$, seria posteriormente complementada pelas suas reflexões em torno do planejamento

13 Faz-se referência à participação de Milton Santos no Seminário Nacional "Reformulação do Estatuto Básico das Regiões Metropolitanas do Brasil”, promovido pela Secretaria dos Negócios Metropolitanos do Estado de São Paulo, em 1985, com o objetivo de apresentar à Assembleia Nacional Constituinte as "diretrizes para o trato das realidades metropolitanas brasileiras pela nossa ordem constitucional” (SÃO PAULO, 1985, não paginado). 
sociopolítico ou da política social da cidade como um contraponto às modalidades técnico-econômicas de planificação (SANTOS, 1993b, 2012b). A flexibilidade tropical das cidades dos países subdesenvolvidos, assentada na diversidade do meio ambiente construído, da população e dos circuitos econômicos (SANTOS, 2013b), apareceria como uma das ideias-força desse "novo planejamento, talvez menos urbanístico e mais urbano; e certamente mais social e mais humano" (SANTOS, 2009, não paginado).

Quando, por ocasião do IV Encontro Nacional da ANPUR ${ }^{14}$, em 1991, Milton Santos fez do título de sua conferência de abertura uma exortação "por um novo planejamento urbano-regional” (SANTOS, 1993a, p. 37), definiu-o como sendo aquele que "desafie as verticalidades que as sociedades locais não podem comandar e imponha contrafinalidades". Nessa definição fazem-se presentes mais duas das ideias-força assinaladas no Quadro 5, quais sejam, a busca de novas horizontalidades e a passagem da racionalidade à contrafinalidade. Ambas expressam uma mesma ideia de fundo: a renovação do planejamento urbano e regional, em um período que (re)cria e aprofunda desigualdades, hierarquias e dependências fundadas no controle corporativo da técnica, da ciência e da informação, pressupõe encontrar os (muitos) limites sociais, econômicos e geográficos da racionalidade hegemônica e, a partir dessas "brechas" (SANTOS, 1993a), redescobrir os mecanismos capazes de levar a uma nova horizontalização das relações socioterritoriais, restituindo às cidades e às regiões algo da capacidade de decisão e gestão da vida urbana e regional e pondo em prática "novas racionalidades, em outros níveis e em regulações mais consentâneas com a ordem desejada. Desejada pelos homens, lá onde eles vivem” (SANTOS, 2013b, p. 54).

Essas reflexões foram mais desenvolvidas por ocasião da participação de Milton Santos em dois eventos acadêmicos que trataram de regiões periféricas do território nacional, representativas do que o geógrafo chamou de regiões do fazer, caracterizadas pela submissão a uma incessante entropia que perturba as solidariedades orgânicas de outrora e impõe novas coesões com base na regulação e no comando remotos; solidariedades organizacionais que são, também, sinônimos de estranhamento, de alienação e da incapacidade de dirigir a si mesmo. Em um dos referidos eventos ${ }^{15}$, foram os grandes projetos

14 Eleito presidente da ANPUR durante esse evento, Milton Santos priorizaria a busca de paradigmas de planejamento urbano e regional adequados para o período técnico-científicoinformacional (SANTOS, 1999a).

15 Trata-se do Seminário Nacional "Grandes projetos: desorganização e reorganização do espaço”, promovido pelo NAEA/UFPA em parceria com a ANPUR, na cidade de Belém-PA, em abril de 1991. Em entrevista com a Profa. Dra. Edna Maria Ramos de Castro (NAEA/ UFPA) (Belém, 23 de maio de 2019), integrante do comitê organizador do Seminário, foinos informado que a pertinência das discussões de Milton Santos sobre o espaço motivou o convite feito para a sua participação no evento. 
na Amazônia, interpretados pelo autor como "grandes objetos" (SANTOS, 1994), que estiveram no centro da análise; no outro ${ }^{16}$, foram as problemáticas do planejamento de uma região entrópica (SANTOS, 1995), o Nordeste, que inspiraram as proposições miltonianas.

Em ambas essas regiões, sugeriu Santos (1994, 1995), a condição para tornar vigentes as contrafinalidades necessárias à renovação do planejamento urbano e regional seria o fortalecimento dos seus estoques próprios de saber. Assentados ao mesmo tempo no conhecimento do mundo (de suas funcionalizações) e do lugar (de seu cotidiano e de sua contiguidade), os saberes locais e regionais seriam aqueles a informar o discurso da política com uma epistemologia da existência, a única capaz de reconduzir o planejamento ao domínio que nunca deveria ter abandonado, o espaço banal, onde vivem e trabalham, na cooperação e no conflito, todas as pessoas, todas as empresas e todas as instituições, independentemente das suas diferenças, porque, afinal, "existindo estão todos" (SANTOS, 1996, p. 14).

Para Santos (1999b), à medida que ganhar espaço essa perspectiva existencial e banal estaremos mais perto do ideal de uma federação de lugares, outra das ideias-força do novo planejamento urbano e regional. Central nessa proposição é a categoria do território usado, pois é a partir dela que se pode "fazer falar a nação" (SANTOS; SILVEIRA, 2012); não apenas a "nação ativa" no processo de globalização, mas sobretudo aquela que, desse ponto de vista hegemônico, aparece como "nação passiva", "constituída pela grossa maior parte da população e da economia [...] estatisticamente lenta, colada às rugosidades do seu meio geográfico, localmente enraizada e orgânica" (SANTOS, 2001b, p. 157). Dotada de um dinamismo próprio de natureza demográfica ou popular, não outorgado por um motor externo, essa seria, de fato, a verdadeira "nação ativa" cujo peso compele a federação a uma reconstrução a partir de baixo, a uma "lugarização" que é condição da cidadania plena:

a realização da cidadania reclama, nas condições atuais, uma revalorização dos lugares e uma adequação de seu estatuto político. A multiplicidade de situações regionais e municipais, trazida com a globalização, instala uma enorme variedade de quadros de vida, cuja realidade preside o cotidiano das pessoas e deve ser a base para uma vida civilizada em comum. Assim, a possibilidade de cidadania plena das pessoas depende de soluções a serem buscadas localmente, desde que dentro da nação, seja instituída uma federação de lugares, uma nova estruturação político-territorial, com a indispensável redistribuição de recursos, prerrogativas e obrigações. Trata-se [...] de uma construção de baixo para cima cujo ponto central é a existência de

16 Faz-se referência ao Seminário Nacional "Teoria e política no pensamento de Celso Furtado", promovido pelo Governo e pela Universidade Federal da Paraíba na cidade de João Pessoa-PB, no ano de 1991. 
individualidades fortes e das garantias jurídicas correspondentes. A base geográfica dessa construção será o lugar, considerado como espaço de exercício da existência plena (SANTOS, 2001b, p. 113-114, grifo nosso).

Nesta que foi uma de suas últimas proposições, Milton Santos expressou uma perspectiva de futuro na qual o planejamento, a partir das células locais que o território usado revela, participa da (re)construção de baixo para cima de uma federação que sirva como uma "casa coletiva" para os diferentes modos urbanos e regionais de ser e de existir.

\section{CONSIDERAÇÕES FINAIS}

Embora ainda relativamente jovem, o campo do planejamento urbano e regional no Brasil acumula um rico patrimônio intelectual cuja especificidade é a confluência entre a lógica interpretativa e valorativa da produção do conhecimento e a lógica operativa e programática da intervenção no espaço (LACERDA, 2013). Neste artigo, procuramos mostrar que Milton Santos foi um dos intelectuais brasileiros que participou ativa e decisivamente da construção desse campo praxeológico, imbricando as duas lógicas dele constitutivas no exercício de atividades político-administrativas e técnico-científicas que são em muito representativas dos diferentes momentos da trajetória do planejamento urbano e regional.

Cabe dizer, no entanto, que a atuação do geógrafo baiano enquanto planejador estadual no início de sua trajetória e as eventuais consultorias que prestou a serviço de instituições governamentais não o definiram como um "intelectual orgânico do Estado", termo utilizado por Barbosa (2020) para se referir a outros pensadores do planejamento, a exemplo de Rômulo Almeida e, até certo ponto, Celso Furtado, que atuaram no e a partir do setor público. Diferentemente, Milton Santos encarnou muito mais a figura do "intelectual crítico da academia" (BARBOSA, 2020), pois foi principalmente a partir da Universidade que desenvolveu suas contribuições para o campo do planejamento urbano e regional.

Embora o tenhamos subdividido em três contribuições, trata-se de um legado único e coerente cujo eixo condutor é o comprometimento com o espaço de todos. Para Santos (1996, 1999b), quando o ponto de partida é esse espaço banal, comum a todos, e não o espaço exclusivo e corporativo de alguns poucos, os elementos da análise e do planejamento tornam-se mais generosos, porque abrangentes da totalidade das formas de existência no espaço. É nessa perspectiva 
que o território usado e a cidadania, as horizontalidades e as solidariedades orgânicas, o saber local e a flexibilidade tropical, as contrarracionalidades e os tempos lentos, os lugares e seus cotidianos, entre outras categorias, conceitos e noções extraídos diretamente do espaço banal, podem vir a estar no cerne de um novo planejamento urbano e regional.

Não se trata de buscar na obra miltoniana soluções e fórmulas prontas a serem indiscriminadamente aplicadas, pois isso seria ir de encontro ao próprio espírito que presidiu a reflexão do autor, para quem hoje, mais do que nunca, são o lugar e o cotidiano os mediadores da produção do discurso político eficaz (SANTOS, 1996). Por conseguinte, o que o pensamento de Milton Santos tem a nos oferecer é um quadro de reflexão cuja generalidade é garantida pela universalidade empírica de nosso tempo, mas cujos elementos de análise devem ser local e regionalmente retrabalhados, reciclados e refeitos (SANTOS, 1999b).

Diríamos, inspirados nas palavras de Brunhes (1910 apud SANTOS, 2012a, p. 17) a respeito da Geografia humana, que o novo planejamento urbano e regional "ainda não está feito, temos ainda de fazê-lo". E a obra miltoniana constitui um valioso patrimônio intelectual para enfrentarmos esse desafio.

\section{REFERÊNCIAS}

ARQUIVO INSTITUTO DE ESTUDOS BRASILEIROS DA UNIVERSIDADE DE SÃO PAULO [IEB/USP]. Fundo Milton Santos. São Paulo: Milton Santos, 2019.

BARBOSA, A. F. Interpretando o fim do ciclo 1988-2016: pode a "parceria" Furtado e Florestan fornecer novas pistas teóricas e metodológicas para entender o presente passado? Novos Rumos, Marilia, v. 57, n. 1, p. 109-130, jan./jun. 2020. BRASIL. Ata da 15a Reunião Ordinária da Subcomissão da Questão Urbana e Transporte, Comissão da Ordem Econômica, em 6 de maio de 1987. Diário da Assembleia Nacional Constituinte: Brasília, DF, ano 1, suplemento ao n. 102, p. 88-107, 23 jul. 1987.

\section{CUNHA, S. R. P. [RE: Sobre pesquisa "A Amazônia em Milton Santos"].}

Destinatário: Helbert Michel Pampolha de Oliveira. Porto Velho, 08 abr. 2019. 1 e-mail. Disponível em: helbertmiche193@gmail.com. Acesso em: 08 abr. 2019.

FELDMAN, S. Entre o regional e o metropolitano: pensamento urbanístico e metrópole no Brasil na década de 1950. Revista USP, São Paulo, n. 102, p. 13-22, jun./ago. 2014. 
FERNANDES, D. A. A questão regional e a formação do discurso desenvolvimentista na Amazônia. 2011. 313 f. Tese (Doutorado em Ciências - Desenvolvimento Socioambiental) - Programa de Pós-Graduação em Desenvolvimento Sustentável do Trópico Úmido, Núcleo de Altos Estudos Amazônicos, Universidade Federal do Pará, Belém, 2011.

FONSECA, P. C. D. Desenvolvimentismo: a construção do conceito. In: CALIXTRE, A. B.; BIANCARELLI, A. M.; CINTRA, M. A. M. (org.). Presente e futuro do desenvolvimento brasileiro. Brasília: IPEA, 2014. p. 29-78.

FURTADO, C. O mito do desenvolvimento econômico. São Paulo: Círculo do Livro, 1976. 122 p.

IANNI, O. Estado e planejamento econômico no Brasil (1930-1970). 4. ed. Rio de Janeiro: Civilização Brasileira, 1986. 316 p.

JAPIASSU, H. O mito da neutralidade científica. Rio de Janeiro: Imago, 1975. 187 p.

LACERDA, N. O campo do planejamento urbano e regional: da multidisciplinaridade à transdisciplinaridade. Revista Brasileira de Estudos Urbanos e Regionais, São Paulo, v. 15, n. 1, p. 77-93, maio 2013.

SANTOS, M. O papel metropolitano da cidade do Salvador. Revista Brasileira dos Municípios, Rio de Janeiro, ano 9, n. 35/36, p. 185-190, jul./dez. 1956.

SANTOS, M. Localização industrial em Salvador. Revista Brasileira de Geografia, Rio de Janeiro, ano 20, n. 3, p. 245-276, jul./set. 1958.

SANTOS, M. Geografia e desenvolvimento econômico. Revista Brasileira de Geografia, Rio de Janeiro, n. 4, p. 99-110, out./dez. 1959a.

SANTOS, M. Fatores que retardam o desenvolvimento da Bahia: a falta de indústrias. Salvador: Imprensa Oficial da Bahia, 1959b. 16 p.

SANTOS, M. A cidade como centro de região: definições e métodos de avaliação da centralidade. Salvador: Universidade da Bahia/Livraria Progresso Editora, 1959c. 31 p.

SANTOS, M. Salvador e o deserto. Revista Brasileira dos Municípios, Rio de Janeiro, ano XII, n. 47/48, p. 127-128, jul./dez. 1959d.

SANTOS, M. Panorama econômico-social da Bahia. Revista Brasileira dos Municípios, Rio de Janeiro, ano 17, n. 67/68, p. 117-124, jul./dez. 1964.

SANTOS, M. Disparidades regionais e polos de desenvolvimento. In: SANTOS, M. A cidade nos países subdesenvolvidos. Rio de Janeiro: Civilização Brasileira, 1965. p. 138-149. 
SANTOS, M. Commerce alimentaire et force régionale de la ville dans les pays sous-développés: une méthode d'analyse. Revue Tiers Monde, Paris, v. 12, n. 48, p. 819-824, 1971.

SANTOS, M. Rêve et cauchemar: problèmes spatiaux de la transition au socialisme - le cas de la Tanzanie. Revue Tiers Monde, Paris, v. 19, n. 75, p. 563-572, jul./set. 1978.

SANTOS, M. Espaço e sociedade: ensaios. Petrópolis: Vozes, 1979. 156 p.

SANTOS, M. Reformulando a sociedade e o espaço. Revista de Cultura Vozes, Petrópolis, v. 74, n. 4, p. 37-48, maio 1980.

SANTOS, M. Organização social e organização do espaço: o caso de Rondônia. Boletim Carioca de Geografia, Rio de Janeiro, ano 33, p. 51-77, 1982.

SANTOS, M. América Latina: nova urbanização, novo planejamento. Orientação, São Paulo, n. 7, p. 47-52, dez. 1986.

SANTOS, M. Passado e presente das relações entre sociedade e espaço e localização pontual da indústria moderna no Estado da Bahia. Boletim Paulista de Geografia, São Paulo, n. 65, p. 5-27, 1987.

SANTOS, M. Por um novo planejamento urbano-regional. In: ENCONTRO NACIONAL DA ANPUR, 4., 1993, Salvador. Anais [...]. Salvador: UFBAANPUR, 1993a. p. 35-39.

SANTOS, M. A urbanização brasileira. São Paulo: Hucitec, 1993b. 157 p.

SANTOS, M. Os grandes projetos: sistema de ação e dinâmica espacial. In: CASTRO, E. M. R.; MOURA, E.; MAIA, M. L. (org.). Industrialização e grandes projetos: desorganização e reorganização do espaço. Belém: NAEA/ UFPA, 1994. p. 13-20.

SANTOS, M. O futuro do Nordeste: da racionalidade à contrafinalidade. In: GAUDÊNCIO, F. S.; FORMIGA, M. (org.). Era da esperança: teoria e política no pensamento de Celso Furtado. São Paulo: Paz e Terra, 1995. p. 99-107.

SANTOS, M. Por uma Geografia cidadã: por uma epistemologia da existência. Boletim Gaúcho de Geografia, Porto Alegre, n. 21, p. 7-14, ago. 1996.

SANTOS, M. Atividades para visibilidade e projeção da ANPUR, 1991-1993. Revista Brasileira de Estudos Urbanos e Regionais, São Paulo, n. 1, p. 19-23, maio 1999a.

SANTOS, M. O território e o saber local: algumas categorias de análise. Cadernos IPPUR, Rio de Janeiro, ano XIII, n. 2, p. 15-26, 1999 b. 
SANTOS, M. Por uma nova Federação. Correio Braziliense, Brasília, 16 jul. 2000. p. 15.

SANTOS, M. Curriculum vitae de Milton Santos. 2001a. 87 p. Disponível em: http://www.miltonsantos.com.br/site/miltonsantos_curriculum.pdf. Acesso em: 06 jan. 2019.

SANTOS, M. Por uma outra globalização: do pensamento único à consciência universal. 6. ed. Rio de Janeiro: Record, 2001b.

SANTOS, M. Entrevista. In: SANTOS, M. [Entrevista cedida a] Jesus de Paula Assis; colaboração de Maria Encarnação Sposito. Milton Santos: testamento intelectual. São Paulo: Editora da UNESP, 2004. p. 11-62.

SANTOS, M. Economia espacial: críticas e alternativas. 2. ed. São Paulo: EDUSP, 2007. 208 p.

SANTOS, M. O centro da cidade do Salvador: estudo de geografia urbana. 2. ed. São Paulo: EDUSP, 2008a. 208 p.

SANTOS, M. O espaço dividido: os dois circuitos da economia urbana dos países subdesenvolvidos. 2. ed. São Paulo: EDUSP, 2008b. 440 p.

SANTOS, M. Cidade pede um novo urbanismo. A Tarde, Salvador, 29 mar. 2009. Disponível em: https://atarde.uol.com.br/bahia/salvador/noticias/1268821milton-santos:-cidade-pede-um-novo-urbanismo. Acesso em: 21 ago. 2020.

SANTOS, M. Por uma geografia nova: da crítica da geografia a uma geografia crítica. 6. ed. São Paulo: EDUSP, 2012a. 288 p.

SANTOS, M. Por uma economia política da cidade: o caso de São Paulo. 2. ed. São Paulo: EDUSP, 2012b. 144 p.

SANTOS, M. O trabalho do geógrafo no Terceiro Mundo. 5. ed. São Paulo: EDUSP, 2013a. 136 p.

SANTOS, M. Técnica, espaço, tempo: globalização e meio técnico-científicoinformacional. 5. ed. São Paulo: EDUSP, 2013b. 176 p.

SANTOS, M. O espaço do cidadão. 7. ed. São Paulo: EDUSP, 2014. 176 p.

SANTOS, M.; SILVEIRA, M. L. O Brasil: território e sociedade no início do século XXI. 16. ed. Rio de Janeiro: Record, 2012. 475 p.

SÃO PAULO. Secretaria de Estado dos Negócios Metropolitanos. Seminário Nacional Reformulação do Estatuto Básico das Regiões Metropolitanas do Brasil. São Paulo: SNM, 1985. Não paginado.

Texto submetido à Revista em 19.01.2020

Aceito para publicação em 19.08.2020 